\title{
Ethnobotanical, Phytochemical and Pharmacological Potential of Cycas revoluta Thunb - A review
}

\section{G.S. Deora, Monika K. Shekhawat*, Sarswati}

\section{G.S. Deora, Monika K. Shekhawat*, Sarswati}

Department of Botany, University College of Science, M. L. Sukhadia University, Udaipur, Rajasthan, INDIA.

Correspondence

\section{Correspondence}

\section{Monika K. Shekhawat}

Department of Botany, University College of Science, M. L. Sukhadia University, Udaipur, Rajasthan, INDIA.

Email-monika.kalipahari@gmail.com

History

- Submission Date: 19-02-2020;

- Review completed: 01-04-2020;

- Accepted Date: 08-05-2020.

DOI : 10.5530/pj.2020.12.164

Article Available online http://www.phcogj.com/v12/i5

Copyright

(C) 2020 Phcogj.Com. This is an openaccess article distributed under the terms of the Creative Commons Attribution 4.0 International license.

\begin{abstract}
Cycas revoluta Thunb. or sago palm is an important species of cycads, endemically found in Japan, especially in southern Japan throughout the Ryukyu Island. The species is of massive ethnobotanical significance and used at large by the poor people and population of hilly areas in famine condition. It is mainly valued for its starch contains and used as fiber to construct cloth and ropes. It shows several pharmacological activities since different parts of this plant contain several chemicals like glycosides, amino acids, flavonoids, fatty acids and lectins. The aim of the present review is to compile all the informations available related to taxonomy, ethnobotany, chemical constituents and their pharmacological activities to explore the importance of $C$. revoluta.
\end{abstract}

Key words: Ethnobotany, Phytochemistry, Pharmacology, Cycas revoluta, Endemic species.

\section{INTRODUCTION}

Cycas revoluta Thunb. is a gymnosperm belonging to the family Cycadaceae. Sago Cycas, Sago Palm Sotetsu Nut, False Sago, ${ }^{1}$ Sago Palm of Japan and king sago palm ${ }^{2}$ are some common name of this species. Cycads have long been known to cause toxicity. ${ }^{3}$ Sago starch requires appropriate processing to eliminate its toxin before use otherwise, it can lead liver damage, vomiting and even death. ${ }^{4}$ In geological time scale, Mesozoic era was the golden period of this plant group. ${ }^{5}$ Many rare and endangered species are present in Cycadacece family. ${ }^{6}$ It is endemic to Japan but originally came from Southeast Asia. At present it is bounded to warm climate that previously found worldwide. ${ }^{7}$ It is a xerophytic plant. ${ }^{4}$ Sago palm is broadly distributed from southern Kyushu to Iriomotejima Island throughout the Ryukyu Islands on the rocky coast. ${ }^{5,8} \mathrm{C}$. revoluta population size is large in several regions. ${ }^{9} \mathrm{C}$. revoluta is widely cultivated trees, occurred in subtropical, tropical and temperate regions..$^{10}$ It is a cycad that easily affected by water logging but can tolerate the drought and frost. ${ }^{1}$ It has a capacity to fix nitrogen in loamy (medium), sandy (light) and well- drained soil. It can grow in basic, neutral and acid soil. ${ }^{7}$ The name of this species of cycads is Cycas revoluta because of its revolving margin of leaflet. It is very good specimen as bonsai. ${ }^{4}$

It has several medicinal properties so its different parts are used to treat many diseases like estrogen dependent carcinoma, cancer, hepatoma, diarrhea and dysentery, flatulence, vomiting, piles and wound. C. revoluta is the utmost famous ornamentals among the cycads. In the Philippines and Indonesia, Cycads leaves are used as a vegetable and root nodules of $C$. revoluta which are edible and have been reported as a 'potato-like' substance. ${ }^{11,3}$ Starch grains that are obtained by its pith and cortical cells of stem are used by the poor people and people of hilly area in starvation condition. Seeds and pulps (removed basal offsets) are used to propagate this species. ${ }^{12}$

In this review the present authors tried to compile all the informations related to its taxonomy, ethnobotanical uses, phytochemistry and pharmacological uses comprehensively to explore the utility of $C$. revoluta.

\section{TAXONOMIC DESCRIPTION}

Cycas revulata is a palm- liked evergreen, slowgrowing, medium sized, perennial, branched with multiple heads, ${ }^{4}$ woody, ${ }^{13}$ 0.5-2 m tall ${ }^{14}$ and 35-95 $\mathrm{cm}$ wide trunked dioecious tree which has a lifespan of more than 100 years..$^{15}$ Stem of young age tree is tuberous while old tree has thick columnar and rough stem. ${ }^{4}$ Glossy green, thick, many, populous, large pinnately compound and 0.5 to $1.5 \mathrm{~m}$ long leaves are found in it that have more than 100 linear leaflets with downward rolled margins and sunken midrib. ${ }^{16}$ Veins are absent in midrib. Main rachis is curled in young leaves. It bears both scaly and foliage leaves which are arranged in alternative manner. Scaly leaves are persistent and brown in colour and foliage leaves are pinnately compound and large with $60 \mathrm{~cm}$ length. Scaly leaves existing in more quantity than foliage leaves and play a role in the protection. Leaves have quadrangular and thicked petiole. ${ }^{4}$ Leaves are produced by the plant throughout the year and last for many years. ${ }^{14}$ The flowers of $C$. revoluta are dioecious it means that both female and male flowers are on different plants and an individual plant has either female flower or male flower. Flowering begins in May and ends in July. ${ }^{7}$ Male cones are characterized by sporophylls, narrowly ovoid to cylindrical, hairy, brown in color and a short up curved point with narrowly wedge shaped whereas loose, open, hairy, brown, densely brown hairs on sporophylls, apical lobe ovate, deeply laciniate margin with 12-18 tapered lobes characters are present in female cone. ${ }^{1}$ Cycas revoluta has 
anemophily and entomophily both type of pollination. ${ }^{14} \mathrm{~A}$ red coated approximately $3 \mathrm{~cm}$ wide and $4 \mathrm{~cm}$ long and seeds are produced by C. revoluta. ${ }^{8}$ Normally seeds of cycads are heavy in weight that's why they sink in water. Seeds of $C$. revoluta show very low percentage of germination. ${ }^{12}$

\section{SCIENTIFIC CLASSIFICATION}

Kingdom- Plantae

Division- Cycadophyta

Class- Cycadophyta

Order- Cycadales

Family- Cycadaceae

Genus- Cycas

Species- revoluta

\section{ETHNOBOTANICAL POTENTIAL OF CYCAS REVOLUTA}

C. revoluta is very important ethnobotanical plant for the local people of hilly areas because it is used by them as medicinal and non medicinal purposes. It contains starch in a very good quantity so it is used as a food by different ways such as sago, flour, bread, cake, vegetables etc. Its different plant parts are also used to household needs and to treat many diseases. Household needs include funeral wreaths, decoration and the making of huts, ropes, cloths, brooms, baskets from plant parts (Table 1).

\section{PHYTOCHEMICAL CONSTITUENTS OF CYCAS REVOLUTA}

Many types of phytoconstituents have been extracted and isolated from different solvents of various plant parts of $C$. revoluta. The potent phytochemicals are lectins, flavonoids, lipids, chitinase, estragole, glycoside, nonprotein amino acid and essential oil. $\mathrm{NaCl} / \mathrm{Pi}$, chloroform, ethyl acetate, methanol, diethyl ether, petroleum ether, and ethanol are some solvents which have been used for extraction (Table 2).

\section{PHARMACOLOGICAL ACTIVITIES OF CYCAS REVOLUTA}

Researchers have been reported many kinds of pharmacological activities in C. revoluta like antiviral, astringent diuretic, antioxidant, antidiabetic, antimicrobial, antibacterial, antileishmanial activity, antifungal, cytotoxic, anticancer, antirheumatic. The detailed pharmacological activities are tabulated in Table 3.

\section{Table 1: Ethnobotanical importance of Cycas revoluta.}

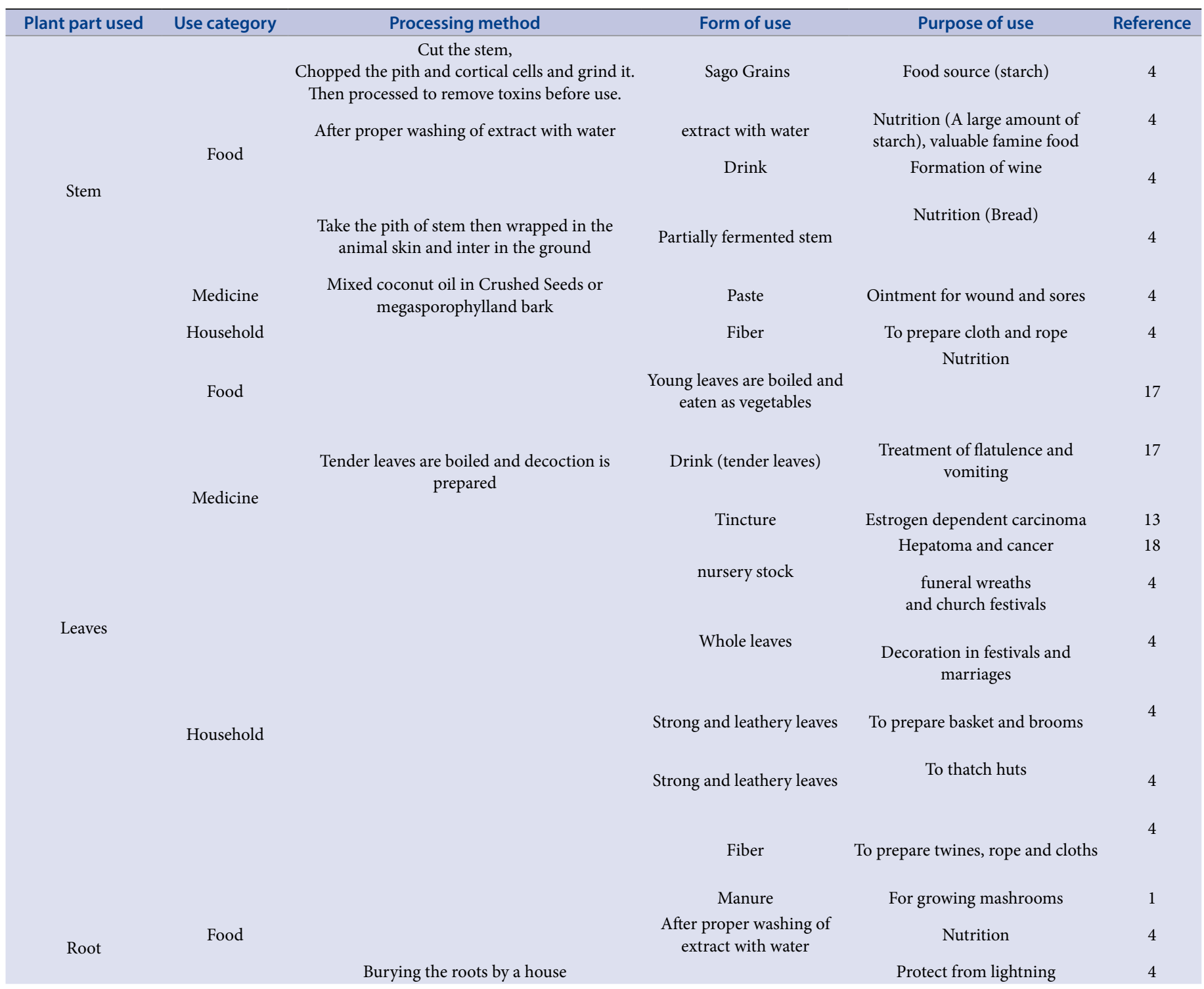




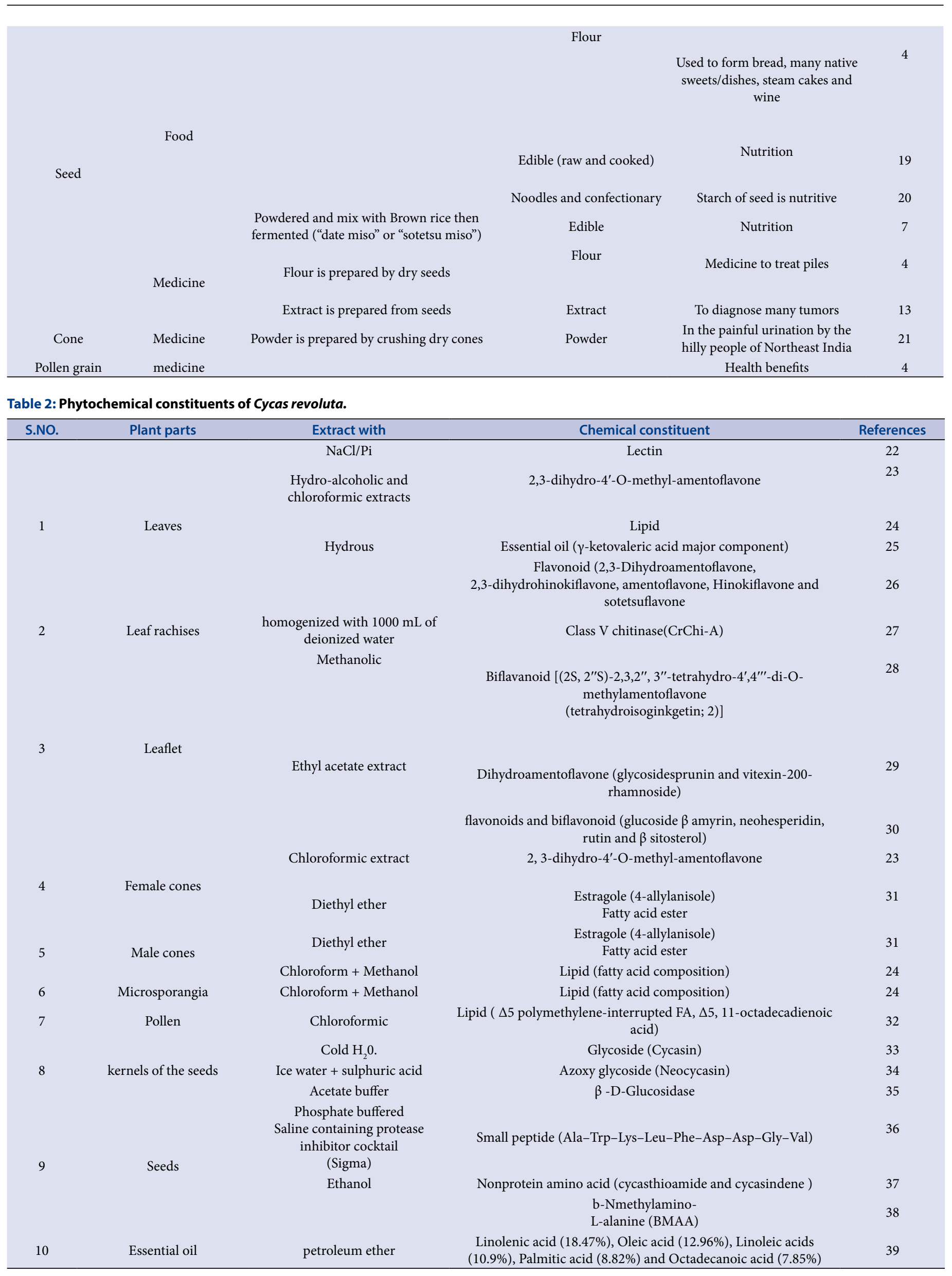




\section{Table 3: Pharmacological activities of Cycas revoluta.}

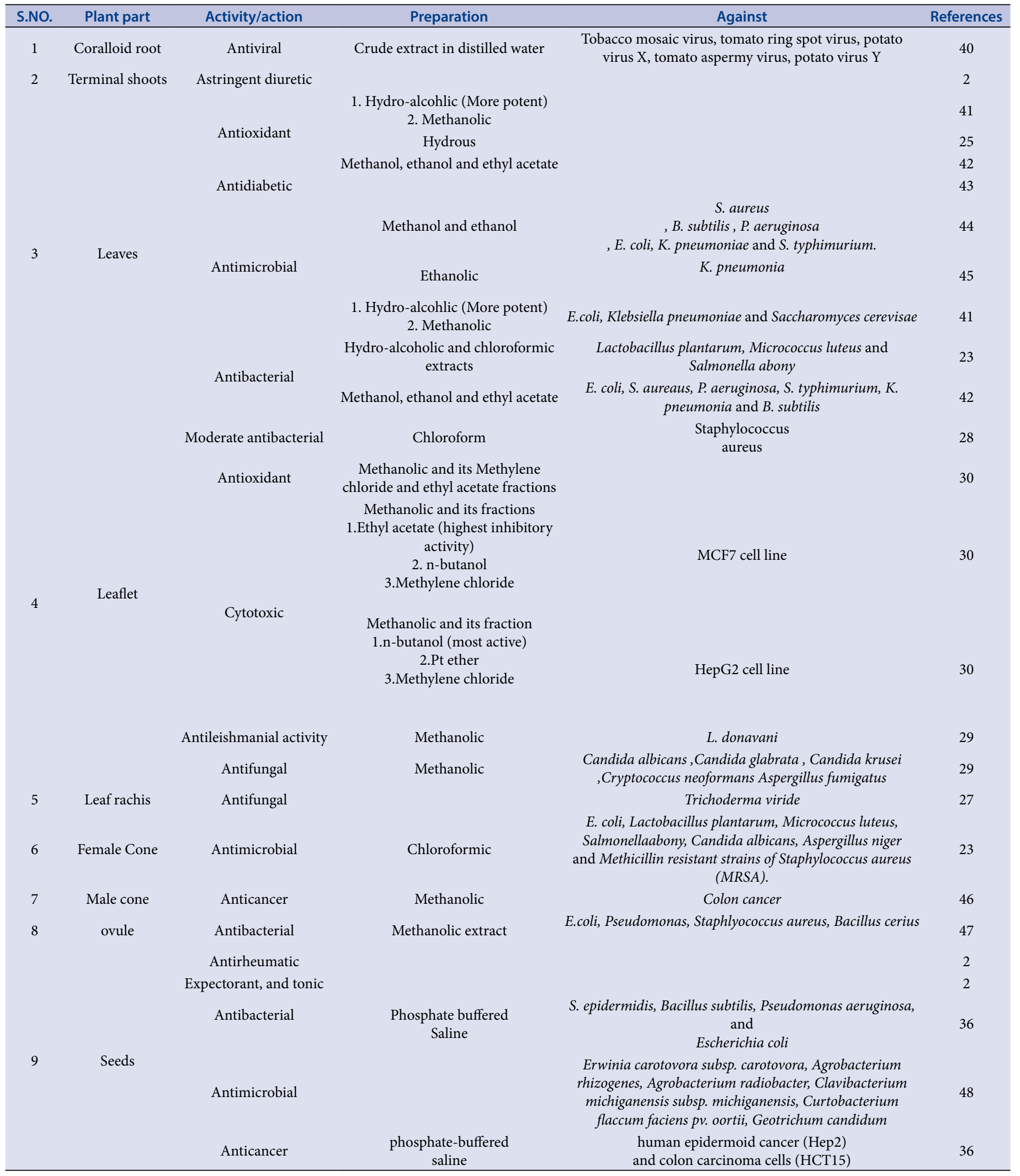




\section{CONCLUSION}

This review comprises ethnobotanical, phytochemical and pharmacological potential of Cycas revoluta. The different plant parts are used as food, medicine, liquor, fiber and other household purposes and also used to cure many diseases like piles, painful urination, flatulence and vomiting by local population of hilly areas. Present review concluded that large number of chemicals like lipids, flavonoid, cycasin, lectin, peptides, biflavonoid are present in this plant hence it shows several pharmacological activities such as antioxidant, anticancer, antileshamanian, antifungal, antibacterial and antimicrobial etc.

\section{CONFLICTS OF INTEREST}

The authors declare no conflicts of interest.

\section{REFERENCES}

1. Lim TK. Cycas revoluta. Edible Medicinal and Non-Medicinal Plants. 2011;1:7328.

2. Duke JA, Ayensu ES. Medicinal plants of China. 1st ed. Algonac, Michigan: Reference Publications; 1985.

3. Whiting MG. Toxicity of Cycads. Econ Bot. 1963;17:270-302.

4. Lal JJ. Sago palm. Elsevier Science Limited; 2003, p.5035-9.

5. Jones DL. Cycads of the world. Reed Books, Chats wood;1993.

6. Kiong ALP, Thing YS, Gansau JA, Hussein S. Induction and multiplication of callus from endosperm of Cycas revoluta. Afr J Biotechnol. 2008;7(23):4279 84.

7. Brenner ED, Stevenson DW, Twigg RW. Cycads: evolutionary innovations and the role of plant derived neurotoxins. Trends Plant Sci. 2003;8(9):446-52.

8. Yamazaki T. Cycadaceae. In: Iwatsuki K, Yamazaki T, Boufford DE, Ohba H (ed.) Flora of Japan. Kodansha, Tokyo;1995,1:263.

9. Kyoda S, Setoguchi H. Phylogeography of Cycas revolutaThunb. (Cycadaceae) on the Ryukyu Islands: very low genetic diversity and geographical structure. Plant Syst Evol. 2010;288:177-89.

10. Khalighi A. Ornamental trees and shrubs of Iran: planting, management and propagation. Tehran Univ Press;2001, p.179.

11. Thieret JW. Economic botany of the Cycads. Econ Bot. 1958;12:3-41.

12. Zarchini M, Hashemabadi D, Kaviani B, Fallahabadi PR, Negahdar N. Improved germination conditions in Cycas revoluta $\mathrm{L}$. by using sulfuric acid and hot water. Plant Omics. 2011;4(7):350-3.

13. Kowalska MT, Itzhak $Y$, Puett D. Presence of aromatase inhibitors in Cycads. J Ethnopharmocol. 1995;47(3):113-6.

14. Kono M, Tobe H. Is Cycas revoluta (cycadaceae) wind- or Insect-pollinated? Am J Bot. 2007;94(5):847-55.

15. Hill KD, Stevenson DW, Osborne R. The World List of Cycads. The Bot Rev. 2004;70:274-98.

16. Gilman EF. Cycas revoluta: General information and description. Review paper of Institute of Food and Agricultural Sciences. Environment Horticulture Department: Florida; 1999.

17. Chopra RN, Nayar SL, Chopra IC. Glossary of Indian medicinal plants (including the supplement). NewDelhi: Council of Scientific and Industrial Research; 1986.

18. Hill KD. Proc. 3rd International conference on Cycad Biology; 1993, p. 139.

19. Chang SS. Acute cycas seed poisoning in Taiwan. J Toxicol Clin Toxicol. 2004;42(1):1119-26.

20. Kira K, Miyoshi A. Utilization of sotetsu (Cycas revoluta) in the Amami Islands. Res Bull Kagoshima Univ For. 2000;28:31-7.

21. Rout J, Sajem AL, Nath M. Medicinal plants of North Cachar Hills district of Assam used by the Dimasa tribe. Indian J Tradit Knowl. 2012;11:520-7.

22. Yagi F, Iwaya T, Haraguchi T, Goldstein IJ. The lectin from leaves of Japanese cycad, Cycas revoluta Thunb. (Gymnosperm) is a member of the jacalin-related family. Eur J Biochem. 2002;269:4335-41.

23. Lal K, Ahmed N, Mathur A. Study of the Antimicrobial Profile and Phytochemical Composition of Solvent Extracts of Leaves and Female Cones of Cycas revoluta. Int J Curr Microbiol App Sci. 2017;6(4):2514-22.

24. Zhukov AV, Kuznetsova El, Pchelkin VP, Sidorov RA, Tsydendambaev VD. Fatty Acid Composition of Lipids from Leaves and Strobila of Cycas Revoluta (Cycas revoluta). Russ J Plant Phys. 2018;65(1):23-9.
25. Olabisi AE, Olubunmi OO. Essential oil compositions and antioxidant properties of Cycas revoluta (Thunb.). GSC Biological and Pharmaceutical Sciences. 2019;9(2):102-9.

26. Geiger $H$, de Pfleiderer WG. Über 2,3-dihydrobiflavone in Cycas revoluta. Phytochemistry. 1971;10(8):1936-8.

27. Taira T, Tajiri $Y$, Hayashi $H$, Onaga $S$, Uechi G, Iwasaki $H$, et al. A novel plant class $V$ chitinase having transglycosylation activity from cycad (Cycas revoluta): purification, characterization, cloning, and posttranslational modification. Glycobiology. 2009;19:1452-61.

28. Moawad A, Hetta M, Zjawiony JK, Jacob MR, Hifnawy M, Marais JPJ, et al Phytochemical Investigation of Cycas circinalis and Cycas revoluta Leaflets: Moderately Active Antibacterial Biflavonoids. Planta Med. 2010;76:796-802.

29. Moawad A, Hetta M, Zjawiony JK, Ferreira D, Hifnawy M. Two new dihydroamentoflavone glycosides from Cycas revoluta. Nat Prod Res. 2014;28:41-7.

30. Negm WA, Ibrahim ARS, Abo El-Seoud K, Attia Gl, Ragab AE. A New Cytotoxic and Antioxidant Amentoflavone Monoglucoside from Cycas revoluta Thunb Growing in Egypt. J Pharm Sci \& Res. 2016;8(5):343-50.

31. Azuma $\mathrm{H}$, Kono M. Estragole (4-allylanisole) is the primary compound in volatiles emitted from the male and female cones of Cycas revoluta. J Plant Res. 2006;119:671-6.

32. Sidorov RA, Kuznetsova El, Pchelkin VP, Zhukov AV, Gorshkova EN, Tsydendambaev VD. Fatty acid composition of the pollen lipids of Cycas revolutaThunb. Grasas Aceites. 2016;67(4):1-5

33. Nishida K, Kobayashi A, NagahamaT. Studies on Cycasin, a New Toxic Glycoside, of Cycas revolutaThunb. J Agric Chem Soc Japan. 1955;19(1):77-84.

34. Nishida K, Kobayashi A, Nagahama T, Numata T. Studies on Some New Azoxy Glycosides of Cycas revoluta Thunb. J Agric Chem Soc Japan. 1959;23(6):4604.

35. Yagi F, Hatanaka M, Tadera K, Kobayashi A. Beta-D-glucosidase from seeds of Japanese Cycad, Cycas revoluta thunb.: Properties and substrate specificity. J Biochem. 1985;97:119-26.

36. Mandal SM, Migliolo L, Das S, Mandal M, Franco OL, Hazra TK. Identification and characterization of a bactericidal and proapoptotic peptide from Cycas revoluta seeds with DNA binding properties. J cell biochem. 2012;113:184-93.

37. Pan M, Mabry TJ, Beale JM, Mamiya BM. Nonprotein Amino Acids from Cycas Revoluta. Phytochemistry. 1997;45(3):517-9.

38. Krü ger T, Mo“ nch B, Oppenhäuser S, Luckas B. LC-MS/MS determination of the isomeric neurotoxins BMAA (b-N-methylamino-L-alanine) and DAB (2,4-diaminobutyric acid) in cyanobacteria and seeds of Cycas revoluta and Lathyruslatifolius. Toxicon. 2010;55:547-57.

39. XuY, Dai QC, Luan ZZ, Xiang Z, Wu J, Fan YL. Analysis Chemical Composition in Cycas revoluta by GC-MS. Medicine and Biopharmaceutical. 2017;950-5.

40. Rao GP, Baghel AKS, Singh RK, Chatterji KS. Antiviral activity of coralloid root of Cycas revoluta extract against some viruses of tomato plant. Experientia. 1984;40:1257-8.

41. Mourya MK, Prakash A, Swami A, Singh GK, Mathur A. Leaves of Cycas Revoluta: Potent Antimicrobial and Antioxidant Agent. World J Sci. 2011;1(10):1120.

42. Zaffar M, Munis MFH, Rasul F, Masood S, Hassan SW, Imran M, et al. Biological assays of plant extracts from Araucaria columnaris and Cycas revoluta. J Food Agric Environ. 2014;12(1):128-31.

43. Arshad M, Mumtaz MW, Chaudhary AR, Rashid U, Ali M, Mukhtar H, et al Metabolite profiling of Cycas revoluta leaf extract and docking studies on alpha glucosidase inhibitory molecular targets by phytochemicals. Pak J Pharm Sci. 2009;32(4):871-4.

44. Shahid W, Durrani R, Iram S, Durrani M, Khan FA. Antibacterial activity in Vitro of medicinal plants. Sky J Microbiol res. 2013;1(2):5-21.

45. Zazharskyi W, Davydenko PO, Kulishenko OM, Borovik IV, Brygadyrenko WV. Antimicrobial activity of 50 plant extracts. Biosystems Diversity. 2019;27(2):1639.

46. Bera S, Das B, De A, Barua A, Das S, De B, et al. Metabolite profiling and invitro colon cancer protective activity of Cycas revoluta cone extract. Nat Prod Res. 2018;1-5.

47. Dwivedi S. Preparation and extraction of antibiotic from ovule of Cycas revoluta. International Journal of Research in Science and Technology. 2016;6(2):49-54.

48. Yokoyama S, Kato K, Koba A, Minami Y, Watanabe K, Yagi F. Purification, characterization, and sequencing of antimicrobial peptides, Cy-AMP1, CyAMP2, and Cy-AMP3, from the Cycad (Cycas revoluta) seeds. Peptides. 2008;29:2110-7. 


\section{GRAPHICAL ABSTRACT}

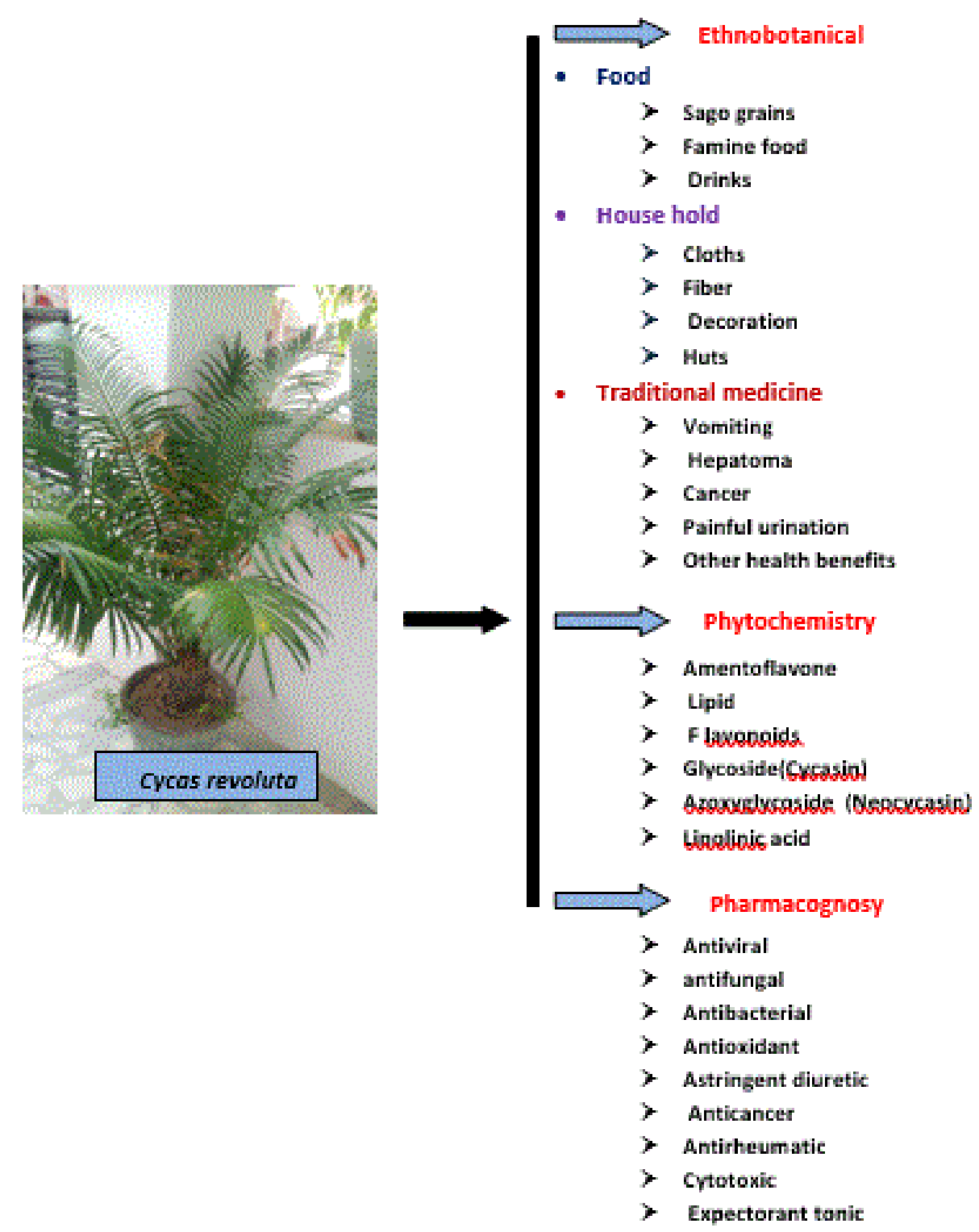

\section{ABOUT AUTHORS}

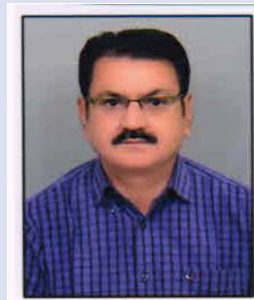

Dr. G.S Deora did his M.Sc. (1986) Ph.D. (1990) in Botany from Mohanlal Sukhadia University, Udaipur (Rajasthan). He has more than 25 years of teaching and research experience at College and University level. Deora is a fellow of Indian Botanical Society (F.B.S), Society of Sciences India (F.S.Sc.), Fellow of Natural Resources Society, India (F.N.R.S.) and life members of many academic bodies. He is a active researcher and guided 11 Ph.D. scholars successfully and 5 are still registered for Ph.D. under his supervision. He has authored 7 text and reference books, published 60 research papers, and attended more than 35 national and international conferences/seminars/symposia. He has been awarded as APSI Innovative Scientist Award by Academy of Plant Sciences India in Nov.2019. 


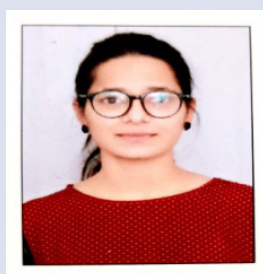

Miss Monika K. Shekhawat did her M.Sc. Botany from Banasthali Vidhyapith Rajasthan. She is NET JRF qualified and actively engaged to explore various active phytochemicals from important medicinal plants of Rajasthan and assess their antimicrobial activity. She has attended several national and international conferences/seminars.

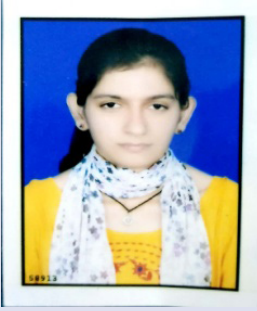

Miss Sarswati has completed her master's degree in Botany (2017) from Jai Narain Vyas University Jodhpur Rajasthan. She has qualified NET JRF and actively engaged to work on phytochemistry and DNA barcoding of certain bryophytes from Rajasthan as a research scholar.

Cite this article: Deora GS, Shekhawat MK, Sarswati. Ethnobotanical, Phytochemical and Pharmacological Potential of Cycas revolutaThunb - A review. Pharmacogn J. 2020;12(5):1165-71. 